\title{
Global Skill Partnerships: a proposal for technical training in a mobile world
}

Michael A Clemens ${ }^{1,2}$

\author{
Correspondence: \\ mclemens@cgdev.org \\ ${ }^{1}$ Center for Global Development, \\ 2055 L Street NW, $5^{\text {th }}$ floor, \\ Washington, DC 20036, USA \\ ${ }^{2}$ IZA-Institute for the Study of \\ Labor, Schaumburg-Lippe-Straße \\ 5-9, 53113 Bonn, Germany
}

\begin{abstract}
Skilled workers emigrate from developing countries in rising numbers, raising fears of a drain on the human and financial resources of the countries they leave. This paper critiques existing policy proposals to address the development effects of skilled migration. It then proposes a new kind of ex ante public-private agreement to link skill formation and skilled migration for the mutual benefit of origin countries, destination countries, and migrants: 'Global Skill Partnerships'. The paper describes how such an agreement might work in one profession (nursing) and one region (North Africa), and offers design lessons from related initiatives around the world.
\end{abstract}

JEL codes: F22, J24, 015

Keywords: Brain drain; Development; Education; Finance; Health; Nurse; Eldercare; Mobility; Aging; Migration

\section{Introduction}

The richest countries show increasing demand for certain skilled services, and skilled workers from around the world are migrating to provide those services. But for some skills, particularly in health care, shortages are global-and skilled migration has the potential to exacerbate shortages in skilled migrants' countries of origin. Policy responses that involve blocking skilled migration may be difficult to implement effectively or ethically, and do little to resolve skill imbalances at the destination.

This note proposes a new kind of policy response to global skill shortages. A Global Skill Partnership is a bilateral public-private partnership to link skill creation and skill mobility in a mutually beneficial and equitable way. Countries of migrant origin and destination agree ex ante who will bear the costs of training skilled migrants, and allow a small portion of the large economic gains from skill mobility to foster skill creation in origin countries. Well-designed partnerships would eliminate and even reverse fiscal drain from origin countries due to new migration, while preserving workers' mobility and providing needed skills at the destination. This note focuses on one profession and one region: It offers examples of why and how a partnership for the training and mobility of nurses might work between North Africa and Europe. But such partnerships could in principle work in various professions and regions.

These partnerships take a dual economic opportunity and turn it into an engine of human capital creation for both origin countries and destination countries. The first opportunity to create value is the very large gap in the price of nursing services between

(c) 2015 Clemens; licensee Springer. This is an Open Access article distributed under the terms of the Creative Commons

Attribution License (http://creativecommons.org/licenses/by/4.0), which permits unrestricted use, distribution, and reproduction in any medium, provided the original work is properly credited. 
migrant-origin countries and destination countries. Nursing services are worth 5-8 times as much, for example, in Western Europe as in parts of North Africa. The second opportunity is that the cost of nurse training at the migrant origin is a small fraction of the cost at the destination. It likewise costs at least 5-8 times as much to train a nurse in Western Europe as it costs in North Africa. Skilled migration can thus create enormous economic value. Global Skill Partnerships share that value in a way that origins, destinations, and migrants can agree to.

This proposal begins by describing global skill imbalances in nursing and discussing four traditional classes of policy response, each of which has important disadvantages. It then sketches why and how a Global Skill Partnership could do better than traditional approaches in some settings, and offers examples in the North African setting. It then lists several design features key to the success of such partnerships, and reviews global experience with related initiatives in the past.

\section{Global skill mismatch and skilled migration: Nurses}

Workers across the world are not acquiring some of the most important skills that their countries demand. This occurs in many sectors, but it is clearest for certain skills in health care. There is a global shortage of nurses, a shortage that takes one of two forms.

\subsection{Two types of nursing shortage}

The first form of nursing shortage is a gap between optimal staffing levels and actual staffing levels, principally in developing countries. Many low-income countries lack the nurses to provide basic coverage to their populations. While Western European countries typically have around 10 nurses per 1,000 population, their neighbors across the Mediterranean have far fewer. There are 3.3 nurses per 1,000 population in Tunisia, 2.0 in Algeria, and 0.9 in Morocco (WHO 2014). Just in these three North African countries, it would take tens of thousands of additional nurses to universally reach basic staffing levels recommended by the World Health Organization, and hundreds of thousands to meet Western European staffing levels. Similarly, Verboom et al. (2006) estimate that by 2025, India will confront a shortage of 740,000 nurses, while the shortage in sub-Saharan Africa will be well over 1 million.

The second form of shortage is an imbalance in the labor market for health professionals, principally in developed countries. Many high-income countries will demand far more nurses than they are likely to train. Estimated Registered Nurse shortages within the next several years include over a million in the United States (BLS 2012), 600,000 in Western Europe (European Commission 2012), 100,000 in Canada (Little 2007), and about 100,000 in Australia (HWA 2012). All of these forecasts are sensitive to assumptions, but it is clear that training of nurses will not rise fully to the level of demand in many advanced economies.

Governments can respond to skill imbalances like these in many ways. Each of these responses faces limits. In health, governments can reduce credit constraints with funding for public training and incentives for private training of new health workers (WHO 2006). But rich countries face funding limits as populations age-raising health service demand while shrinking the tax base. Poor countries face even tighter constraints. Governments can also foster international trade in health services. They can make it easier for people to purchase health services in countries where costs are lower, known as "medical tourism" 
(Mattoo and Subramanian 2013), such as by reducing policy constraints on the portability of health insurance (Mattoo and Rathindran 2006).

\subsection{Nurse migration-and its risks}

An alternative response-fostering migration by skilled workers -is very likely to play a role in reducing some of these imbalances. Employment-based migration is controversial everywhere; but in health, it is already happening. Large fractions of the health workforce in some countries got their training in other countries. In the United States, $7 \%$ of registered nurses (Auerbach et al. 2012) and 25\% of physicians (AMA 2010) were trained abroad. Governments from Germany to Japan have tested programs to attract health workers from abroad.

Health worker migration has raised important concerns about its potential effects on the countries of origin. A central concern is that the movement of health workers from less-developed countries will deplete the human resource base of already-weak health systems (WHO 2006). These concerns are so acute that the term "brain drain" is often used as a synonym for skilled migration, with health worker migration seen as its worst face (Grignon et al. 2012). Destination countries that allow migration have been accused of causing deaths in migrant origin countries by failing to limit these "fatal flows" (Joint Learning Initiative 2004, p. 102).

A separate concern is that health worker migration can deplete public coffers in the countries that migrants leave. Even when those countries are able to train replacements for those who migrate, this training often occurs at public expense. One country's taxpayers can, in effect, end up subsidizing other countries' health systems (WHO 2011). This can be globally inefficient, because it encourages migrant destination countries to 'free ride' on the training resources of origin countries-possibly leading to socially inefficient underprovision of training. When the destination country is much wealthier than the origin country, this also raises concerns about justice. It is estimated that tens of thousands of dollars in public subsidies are lost each time a Registered Nurse emigrates from Kenya (Kirigia et al. 2006) or Malawi (Muula et al. 2006). Mills et al. (2011) estimate a cumulative total training cost of US $\$ 2.2$ billion for African-trained physicians residing in Australia, Canada, the United Kingdom, and the United States.

All of this has led to something of an impasse: In nursing, rich countries face pressure to raise skilled migration in response to local shortages and demographic forces. But they simultaneously face pressure to limit skilled migration in response to concerns about development impacts overseas. The next section describes four existing classes of proposals to address this impasse-and their drawbacks. Thereafter the paper proposes a new approach.

\section{Four existing approaches to limit the development impact of nurse migration}

Broadly speaking, policymakers have four existing options to limit the development impacts of skilled migration. This section reviews those options for the case of nurse migration-and their drawbacks. Thereafter, the paper will propose a new, fifth option.

\subsection{Limit migration?}

The first class of policies seeks to limit the ability of skilled workers to choose migration. This can involve preventing destination-country recognition of migrants' skills 
(Gish and Godfrey, 1979), 'self-sufficiency' policies at destination countries to prevent migrants from working there (e.g. WHO 2011, [Article 5.4]), and treating international recruiters of skilled workers as unethical or even criminal (Mills et al. 2008).

All proposals to obstruct migration on development grounds face important obstacles. First, it is unclear how effective these policies are in limiting skilled migration. Second, even successfully blocking skilled migration may not address skill shortages. If migrant-destination countries could somehow force return migration by half of all expatriate African doctors and nurses, this would only eliminate $6 \%$ of Africa's shortage of doctors and nurses, as estimated by the World Health Organization (OECD 2007, p. 178). Third, proposals to obstruct skilled migration are ethically and legally complex. Article 13.2 of the United Nations Universal Declaration of Human Rights sets forth the unqualified right to leave any country. This right could be undermined by bans on "active recruitment", because skilled workers' professions are often only basis for them to lawfully migrate. (If firms' "active recruitment" of women were banned, would this not undermine women's unconditional right to work?) Fourth, restricting individual choice can have important efficiency effects. An Ethiopian doctor's best contribution to medical science, for example, might only be possible with the resources available to her abroad.

\subsection{Compensation payments after migration?}

Another way for governments to offset fiscal losses associated with skilled emigration is to demand cash compensation for costs incurred through subsidies to migrants' training (e.g. Agwu and Llewelyn 2009; Chen et al. 2011; Mills et al. 2013). These might come from destination-country governments or from migrants themselves.

Such policies also face important difficulties. The financial loss is difficult to calculate given that many skilled workers provide substantial service prior to migration. Africantrained physicians in the United States and Canada typically practiced in their home country for over seven years, on average, before departure (Clemens 2011). It is unclear that the cost of basic education should be included, as Mills et al. (2011) suggest it should be, since most origin countries consider basic education a right that is not contingent on subsequent movement. Destination countries' priorities for human capital subsidies in origin countries might differ from origin countries' own priorities, making compensation payments politically vulnerable (Clemens 2009). And aid flows are substantially fungible (e.g. Pack and Pack 2009), so even aid earmarked for human capital creation may not cause more human capital to be created.

\subsection{Domestic efficiency measures?}

Another way for policymakers to counteract the effects of skilled migration at the origin is to make the most of the human resources they are left with. For example, the effect of a health worker's departure on local health conditions can be mitigated by increasing the effectiveness of remaining health workers.

In developed countries, many rural areas use efficiecny measures to adapt to outmigration. For example, many US states with shortages of highly trained health workers have adopted laws empowering qualified by lower-level health workers to do more for patients ${ }^{1}$. In low-income countries, there are likewise many ways to improve the effectiveness of skilled workers who choose not to migrate. In the health sector this can imply meaningful incentives to provide primary care in slums and rural areas; focusing 
training efforts on prevention and basic primary care rather than higher-level tertiary care; giving providers the medicines and tools they need to practice effectively; and dismantling domestic barriers to independent practice by well-trained nurses. Clemens (2009) explores these measures.

\subsection{Oblige return migration?}

An alternative approach is to allow skilled workers to migrate for limited periods, then require them to return home. Many policy approaches to skilled migration contain such requirements. Many countries have training programs of one sort or another that oblige skilled migrants to return to their home countries after a limited period. Brazil and Turkey, among others, have mechanisms to pay for their nationals' graduate education overseas in exchange for a commitment of service in the home country ${ }^{2}$. Each requires that migrants return home for a few years.

Return-migration programs face important limitations. In projects to encourage return among skilled expatriates, only small fractions of migrants take up the offer McCabe et al. (2009). Return migration of skilled workers has happened at scale primarily when the country of origin creates the incentive for return-as occurred in Taiwan (Chang 1992; Saxenian 2002). Moreover, skill shortages in many destination countries are long-term. The demographic transition will not soon reverse course in Germany and Japan; nurses will be needed there and elsewhere for the foreseeable future. Permanent migration best serves long-term needs.

\section{A new approach: linking skill creation to skill mobility}

Policymakers have a fifth, barely-explored option to address the development effects of skilled migration while preserving its global benefits. Countries of origin and destination can enter a new kind of bilateral agreement, a Global Skill Partnership. Two governments in a Global Skill Partnership agree ex ante on how to share the costs and benefits of creating skills for both countries' needs, while preserving workers' freedom of movement. These partnerships could occur in any technical field that is in global demand, but this section focuses on their application to nursing.

\subsection{Key elements of a Global Skill Partnership}

The heart of a Global Skill Partnership is a pre-migration agreement between two countries. The governments and any private-sector partners agree on who at the destination will help finance migrants' training, what portion of training will occur at the origin and to what standard, who will offer employment at the destination under what conditions, and how the benefits of skilled migration will support training for non-migrants. The agreement shapes the financing for training skilled migrants in such a way that it creates, rather than depletes, human capital in the origin country. At the same time it meets the needs of the destination country while opening opportunities for migrants.

One form of Global Skill Partnership could be a two-track technical school for nurses. Such a school would be a technical training institute in a developing country, where each student at entry must choose one of two tracks or courses of study. An 'away' track would train students to work abroad, in a developed country-permanently or temporarily. A 'home' track would train students to work in related jobs inside the country of training. Training for 'away' students could be financed either by destination-country employers 
or governments, or by graduates' future earnings through a form of migration-contingent student loan. This financing would contain a partial subsidy to the training of 'home' track students - a social training credit-fostering and financing a supply response to nurse mobility.

Such a partnership could take many forms, according to the division of rights and responsibilities between the partners. Training could occur entirely in the origin country, or could begin at the origin and conclude at the destination. Financing could occur through the destination-country government, destination-country firms, through the students themselves, or some mix of these. Support for origin-country training could be large or limited.

\subsection{Two engines of human capital creation}

A Global Skill Partnership creates a financial mechanism to realize and share the benefits of two large arbitrage opportunities - turning them into engines of skill creation at the origin and the destination. These opportunities are illustrated here for nurses who move from North Africa to Europe, but similar opportunities exist all over the world.

The first opportunity is that the market value of nursing services is several times higher in Europe than in much of North Africa. Monthly wages of professional nurses commonly fall in the range US\$400-500 in Morocco (Lebsir 2009) and Tunisia (Lautier 2005, p. 47$)^{3}$. Foreign-trained nurses can start at US $\$ 2,500-3,000$ per month and soon progress to $\$ 4,000$ in Germany and France ${ }^{4}$. This means that the mobility of nursing services from North Africa to Europe creates enormous economic value, like all movements of goods and services across an arbitrage opportunity. In the absence of some form of Global Skill Partnership, this value accrues to migrants and destination countries.

The second opportunity is that the cost of nurse training in North Africa is a small fraction of the cost in Europe. A full three-year course of training in professional nursing can be had in the largest urban centers of Morocco and Tunisia for less than US\$14,000 total. In smaller cities the cost can be considerably less ${ }^{5}$. The full cost of training a professional nurse in Germany or the United Kingdom falls in the range is US\$80,000-US\$100,000 total, or more, without living expenses ${ }^{6}$. This likewise means that the mobility of nurse training from Europe to North Africa can create enormous economic value. And again, in the absence of a bilateral agreement, this value accrues to migrants' destination countries.

These numbers imply that training at the origin followed by service at the destination creates tremendous economic value. Three years of training a single nurse in North Africa followed by five years of service in Western Europe can create on the order of US\$70,000-80,000 or more through the training cost differential and an additional US\$120,000-150,000 or more through the wage differential. This means that the total added value of the arrangement would exceed US $\$ 200,000$ even if the final year of training occurred in the destination country.

A Global Skill Partnership ensures that this added value is shared in a way that all parties can agree to. Without any agreement, value accrues exclusively to migrants and destination countries, and is widely seen as inequitable. In a partnership, origins and destinations agree $e x$ ante that a small portion of the added value be directed toward nurse training at the origin-both for the migrants and to some degree for non-migrants. This lets the dual arbitrage opportunity play its role as an engine of human capital creation for the destination country while playing the same role at the origin. 


\subsection{Examples in a North African context}

Here are schematic examples of how a two-track technical school might work in Tunisia, to prepare nurses wishing to work in Germany:

Maryam and Youssef are two young, low-income Tunisians interested in training to work as nurses. Maryam wants to work in Germany, Youssef in Tunisia. The federal government of Germany finances an intensive German language course for Maryam, after which the state government of Bavaria pays for one year of Maryam's technical coursework in nursing (partly in German) as well as one year of Youssef's coursework (in French or Arabic). All of this training occurs in Tunis. After this, Maryam moves to Bavaria to begin a two-year apprenticeship with a hospital, while Youssef completes his training in Tunis and works there. As in a standard German apprenticeship, Maryam's training is financed jointly by the employer and the state. The Bavarian government saves money from the much lower cost of conducting Maryam's coursework in Tunis relative to a standard apprenticeship. A small portion of that savings goes to subsidize Youssef's training.

In an alternative structure, the schools could be self-financing:

Maryam and Youssef train as nurses entirely in Tunis. Maryam plans to work in Germany, Youssef in Tunis. Training each of them costs US\$10,000, and neither can afford it. A private hospital group in Germany finances all of Maryam's training and half of Youssef's, for a total of US\$15,000. In return, Maryam commits herself to work within its hospital network for at least four years. With just $12 \%$ of Maryam's earnings over that period, she pays back the entire US\$15,000. Alternatively, Maryam could 'buy out' her commitment to the original hospital group by switching employers and paying cash to offset her training costs.

And in another structure, training could be split between the two countries:

Maryam plans to work in Germany, Youssef in Tunis. Both train as nurses for one year in Tunis, while Maryam takes intensive German language classes that Youssef does not. The two then separate: Maryam completes two additional years of training in Germany, Youssef completes his training in Tunis. The German employer and public save US\$25,000 or more from covering the cost of Maryam's first year in Tunis rather than in Germany, as they would normally have to, even including the cost of Maryam's Germanlanguage training. They thus agree to share the savings with Tunisia-providing a US\$5,000 subsidy to cover half the cost of Youssef's full course of study in Tunis. From the standpoint of the German employer, Maryam is a normal trainee but for the attraction of her reduced training cost, and there is little doubt of her skill level since her training has mostly occurred at and has been completed at German institutions ${ }^{7}$.

These examples are merely illustrative and many details could change. But observe the consequences of any of the above arrangements (Table 1): Germany gains a nurse (Maryam) whose net earnings are still eight times what she could earn in Tunisia; the German employer saves money, ending up with less net expenditure on training than in an normal apprenticeship and gains a profitable employee; Tunisia gains a nurse (Youssef) with a sizeable free scholarship; two low-income Tunisians get professional careers that 
Table 1 How a Global Skill Partnership beats the status quo in skilled migration

\begin{tabular}{ll}
\hline Actor & Benefit \\
\hline Destination country & - Workers for shortage occupations \\
\hline Destination employer & - Lower public training expenses \\
\hline Migrants & - Custom-trained workers \\
& - Reduced training expenses \\
& - Recruitment facilitated at origin \\
\hline Origin country & - Professional employment \\
& - International-quality training \\
& - Access for students from low-income backgrounds \\
& - Large rise in earnings \\
\hline & - Subsidized training for 'home' track professionals \\
& - Greater supply of professionals at origin \\
& - No fiscal drain from graduates' migration \\
& - Stronger in-country training institutions \\
& - Technology transfer for customized training \\
& - Remittances from 'away' track graduates \\
\hline
\end{tabular}

are otherwise inaccessible; Tunisia expands the capacity and quality of its nurse training facilities; and there is no cost at all to the German or Tunisian governments. Other benefits to Tunisia could arise if Maryam chooses to remit some of her earnings home, or return one day to work in Tunisia.

And the framework could be flexibly adapted to different settings: First, two-track schools schools could include nursing assistants and personal care workers, in addition to or instead of full professional nurses. Second, they could begin with health professionals, but the same framework could later be applied to various types of training to fill semi-skilled and skilled labor shortages in Europe. Third, the arrangement for graduates to live and work in Europe could be temporary or permanent, according to the needs of the destination country or even decided on an individual basis.

Note that an arrangement of this kind would be less expensive to destination country consumers and taxpayers than other ways of supplying their demand for nurses. Very large rises in pay for nurses might induce more natives of destination countries to become nurses. But they would be trained at destination-country cost-a cost borne sooner or later by patients or taxpayers. And even substantial increases in the nursing wage bill are unlikely to induce nursing labor supply that will match demand in some destination countries (Buerhaus et al. 2009; Spetz and Given 2003).

\subsection{The two-track system}

The all-around benefits in Table 1 are possible simply because the labor of a nurse is worth enormously more money in Germany than in Tunisia, and the cost of training a nurse is enormously lower in Tunisia than in Germany. A two-track school can turn these price differences into an engine of human capital creation on both sides of the Mediterranean. And two-track training requires little or no up-front cost to students and is thus accessible to students of any income level. Training for migrants costs origin-country taxpayers nothing and subsidizes the creation of professionals in the home country through the 'home' track, reducing fears of 'brain drain'. Graduates who do not migrate pay much lower tuition, heavily subsidized by a small portion of migrant graduates' earnings. The 
essence of the financing mechanism resembles a new type of student loan-tailored to the international context, and contingent upon the ability to pay that arises through migration.

Why would students choose the domestic track? Large numbers of skilled workers (and health workers in particular) from developing countries simply do not wish to emigratefor a range of personal and professional reasons. Earnings are far from the only factor in health workers' migration decisions (e.g. George et al. 2013). In the Philippines, where overseas opportunities for nurses are widely available, so many nurses choose to stay and work in their home country that the Philippines has high nurse staffing ratios-more, per capita, than Great Britain and Austria (Clemens 2009).

Even from very low-income countries, many health professionals do not wish to migrate. Awases et al. (2004) survey 2,382 nurses, doctors, and pharmacists in Cameroon, Ghana, Senegal, South Africa, Uganda, and Zimbabwe. They find that $51 \%$ of respondents have no intention of emigrating. Avato (2009, Figure two) reports survey results on 3,834 workers in Tunisia, Egypt, Moldova, and Albania, from numerous professions. Among tertiary-educated workers, about one third of Tunisians and Egyptians have no intention of emigrating, as well as about two fifths of Albanians and two thirds of Moldovans. Large numbers of skilled workers in general, and health workers in particular, are interested in training to work in their countries of origin. Furthermore, developing countries participating in arrangements of this kind could cap enrollment in the 'away' track at any level desired.

\section{Key design elements and lessons from related initiatives}

Many governments and firms have created programs that somehow link training to skilled migration. Each of these programs differs substantially from a Global Skill Partnership, but offers lessons on their proper design. Some of these experiences demonstrate that a key element of a Global Skill Partnership is possible, while others suggest possible pitfalls.

\subsection{Financing mechanism}

In a Global Skill Partnership, training finance is provided before migration and recouped after migration. The parties to the agreement are separated by both distance and time. Such a financing scheme requires contracts spelling out the obligations of each party, reliable payment systems, secure records, and a mutually-agreed division of the financial burden of training subsidies, among other elements.

Many private-sector programs have created mechanisms for overseas employers to finance pre-migration skill acquisition for new hires. Shipping companies help finance pre-departure technical training for migrant seafarers at several centers in migrants' home countries. These include the Mapúa-PTC College of Maritime Education and Training in the Philippines, and the Kiribati Marine Training Center in Kiribati. Construction firms in Singapore finance pre-migration technical training for migrant laborers through training centers operated by Virsagi Management in Bangladesh and India.

Related private-sector mechanisms have been created for nursing as well. Nurses Now International (NNI) was a Mexican firm financing training in Mexico for nurses to work in the United States, operating from 2008 to 2012. NNI selected Mexicans with basic nursing training and provided six months of intensive training in advanced nursing methods and 
English language, financing the cost of training and a stipend. Graduates were then placed at partner hospitals in the US for two months of additional training followed by three or four years of nursing work, using skilled work visas created by NAFTA. This migration typically raised their earning potential by roughly $1,000 \%$-from about US $\$ 400 /$ month in Mexico to US\$4,500/month in the US-and 5-10\% of those earnings were used to pay back the cost of their training (Oviedo 2009). The financing mechanism appears to have worked well for individual graduates. But the company began operations just as the Great Recession struck the United States, limiting demand for graduates and eventually causing investors to pull out (Squires and Beltrán-Sánchez 2013, pp. 30-35). NNI received certification from the Alliance for Ethical International Recruitment Practices.

Other, related initiatives receive some type of public facilitation. In Germany at the time of this writing, a suite of agreements is being piloted by the German Society for International Cooperation (GIZ) together with employers in eldercare and nursing. In one of these, employers are working with GIZ and the German Ministry for Economic Affairs to finance pre-migration German-language training and nursing skills training for 100 Vietnamese young people in Vietnam, followed by an abbreviated two-year apprenticeship in geriatric nursing in Germany. By allowing Vietnam-acquired nurse training to substitute for the first year of the German apprenticeship, this program represents an innovative internationalization of the apprenticeship model. Like most German apprenticeships, it is jointly financed by employers and the government.

Issues in the financing mechanism appear to have arisen in another innovative initiative of this type. German private hospital group Asklepios recently worked with the Ministry of Foreign Affairs to create a nurse migration partnership with Tunisia called the TaPIG Project. Groups of Tunisian students arrived in Hamburg in late 2012 and early 2013 for six months of German language and culture training (paid by the Foreign Affairs Ministry) to be followed by three years of apprenticeship training in nursing, paid by Asklepios. The financing mechanism involved an additional component of a student loan to cover other expenses of the students, such as room and board during the language and culture training. Complications with those loans appear to have led to suspension of new entries in the the TaPIG Project at the time of this writing (though Asklepios intends to continue the training of previous entrants). The TaPIG experience suggests that the precise financing mechanism may be critical to progress in arrangements of this genre.

\subsection{Training customization and quality control}

Global Skill Partnerships require ways for destination-country employers to work with origin-country training centers to ensure that students receive high-quality training in the areas that employers need. This will help ensure graduates' successful placement, as well as exerting upward pressure on training quality at the training institute more generally-including in the 'home' track. A great deal of infrastructure already exists. All major migrant-destination countries have systems for testing foreign-trained health professionals' skills, such as the National Council Licensure Examination (NCLEX) in the United States and the Overseas Nurses Program in the United Kingdom. US studies of foreign-trained nurses (Cortés and Pan 2012) and doctors (Norcini et al. 2010) find them to be of comparable quality to their US-trained counterparts. The aforementioned project of GIZ is testing mechanisms to ensure the quality and relevance of training acquired in Vietnam. 
In another German pilot called the "Triple-Win Project", GIZ helps employers recruit qualified health workers from Serbia, Bosnia, the Philippines, and Tunisia. In this project, GIZ helps arrange professional training, language training, and integration assistance in the country of origin-before migration-which is fully financed by the workers' future employers in Germany. Beyond these, Germany is also the setting for multiple initiatives of this kind in the private health sector. The Arbeitgeberverband-Pflegea private nursing home network-is supporting the training of eldercare workers in China for both German language and technical training. These initiatives show that it is at least possible to set up training facilities of international quality in developingcountry settings, though the potential to expand such training to larger scale remains unproven.

In another example from Finland, the surgical wards of Helskinki University Central Hospital have recruited nurses from the Philippines in a way that divides their training between the two countries (Wildau 2011). Entrants to the program already have nursing degrees from the Philippines, and must complete one year of additional training at the Laurea University of Applied Sciences while undergoing intensive Finnish language training. Because the Laurea program normally lasts three and a half years for Finnish entrants, training from the Philippines substitutes for two and a half years of Finland-based training. The end result is that, in effect, these nurses' training is taking place partly in the Philippines and partly in Finland. The private Finnish firm Attendo has likewise recruited Filipinos already qualified as nurses to undergo language training and additional vocational training in Helsinki, financed in part by the Trade Union for the Public and Welfare Sectors, JHL (Jokinen 2013). Here, again, the recruits' preparation as nurses is in effect split between the Philippines and Finland.

The importance of quality control is highlighted by the Kiribati Australia Nursing Initiative (KANI). In 2006, Australia created KANI to train i-Kiribati students as nurses in Australia and for service in Australia. To date, scores of students have been trained to date at Griffith University in Australia. The program is not broadly perceived as promising and appears unlikely to continue. Many graduates have had difficulty in passing licensure examinations and securing professional employment in Australia, despite nursing shortages there. Officials familiar with KANI suggest in personal communications that the project could have benefited from more stringent up-front selection of students. But I am not aware of a publicly-available independent evaluation that would clarify KANI's lessons.

\subsection{Contingency plan}

There will certainly be students in the 'away' track who cannot or will not migrate, just as there may be students in the 'home' track that attempt to migrate. A successful two-track school will require a plan for how to address these scenarios. Training credits to 'away' track students who do not migrate might be fully or partially forgiven, with allowances made for these eventualities in the financial plan. Migration among 'home' track students may be limited if their training does not include extensive foreign-language preparation and placement assistance.

Employers and financiers involved in any such partnerships would need assessments of the risks involved and provisions for unintended outcomes. Two of the German initiatives described above-the TaPIG Project and the Arbeitgeberverband-Pflege partnership- 
built into their initial designs a provision for trainees who are either unable to migrate, unable to remain, or unable to complete satisfactory work.

The need for these plans was illustrated by a nurse training program negotiated between Canada and Jamaica. In late 2009, the Canadian and Jamaican governments created a program to train Licensed Practical Nurses in Jamaica for service in Alberta, Canada. The course of study was 18 months. Training was conducted at the Pre-University School in Kingston, Montego Bay, and Portmore, and was accredited by NorQuest College in Alberta. It was created by an agreement between the Canadian High Commission and the Jamaican Ministry of Labor, brokered by the private firm Marmicmon Integrated Marketing and Communications. Students covered the cost of training and recruitment with the expectation of high earnings in Canada.

The Canada-Jamaica program was discontinued in late 2011. There is no publiclyavailable independent evaluation of the causes of this closure. Reid (2012) reports that of the 156 students who had completed training by May 2011, only 30 had departed for Canada. NorQuest canceled its contract with the Pre-University School in 2011. Even students who did not migrate were required to pay up front $\$ \$ 270,000$ tuition, $C \$ 1,500$ to Marmicmon and C $\$ 300$ to NorQuest. A central problem was that many of the students were unable to complete practical portions of their training in Jamaica-required for licensing in Canada-because the Pre-University School had accepted students unable to enter practical training for technical reasons (Reid 2011). There also appear to have been unexpected delays in placing even fully qualified graduates with employers in Canada, disagreements over cost sharing between Canadian and Jamaican partner institutions, and a lack of employer participation in training finance to diminish students' risk exposure.

\subsection{Skill recognition and employer leadership}

A Global Skill Partnership cannot function as intended unless it creates skills that employers proactively demand-in both countries-and provides mechanisms for the mutual recognition of those skills. Employers must be directly involved from the beginning, for few other actors are likely to push sufficiently hard against political and administrative barriers against labor mobility. This is suggested by a related initiative in the Pacific Region that has resulted in little labor mobility.

The Australia Pacific Technical College (APTC) is a network of five technical training campuses in the developing Pacific Island states of Vanuatu, Samoa, Fiji, Papua New Guinea, and the Solomon Islands. It was created in 2007 to offer Australia-recognized training qualifications for electricians, chefs, hospitality workers, and other skilled tradespersons. It was designed and subsidized by Australian aid to serve two goals: to build up human capital on the islands, and to provide skilled workers for shortage occupations in Australia. In this role it internationalizes skill creation. The second of these goals has been largely discarded as the APTC evolved. Just 1.2\% of the APTC's roughly 5,000 graduates have moved to Australia or New Zealand since the College was created.

Clemens et al. (2014) explore the reasons for this shift away from international mobility for skilled graduates. Some of these are: 1) Beyond their Australia-recognized diploma, graduates also need Australian recognition of work experience to qualify for most temporary and settler visas. The process for this recognition is difficult and expensive and the APTC has no involvement. 2) The APTC was largely the personal initiative of one Prime Minister, and it received substantially less support when he left office shortly 
after it was created. It was not created at the insistent demand of other Australian interest groups, especially employers. 3) The curriculum was not built around occupations with critical shortages.

\subsection{Destination-country labor involvement}

It is critical to design programs of this kind in cooperation with labor unions or employees' associations at the destination. In the nursing and personal care sector, for example, workers' associations at the destination are likely to express a legitimate interest in the effects of foreign trainees on their own working conditions and negotiating power. The possibility of conflict might be reduced by focusing training on shortage occupations, but is unlikely to be eliminated.

An example comes from East Asia, where in 2008 Japan began a program to attract nursing trainees from Indonesia and the Philippines under Economic Partnership Agreements or EPAs (Ogawa 2012; Ohno 2012). These programs attract entrants who already have training and experience as nurses or care workers, and the program does not include a component to finance that origin-country training. But the Japanese government does pay for recruitment, travel, and living expenses of participants, while employers pay for six months of Japanese language training. Once arrived in Japan, program entrants become nursing and certified care-worker "candidates", working legally without a license until they pass a stringent licensure examination of technical skills and Japanese language ability.

This program has faced difficulties because most entrants have failed the licensure exam. A total of 1,360 candidates entered Japan during 2008-2011. Of the first migrants who took the exam in 2010, just $1.2 \%$ passed. In $2011,4.0 \%$ passed. This licensure exam was instated at the request of the Japan Nursing Association out of concern for "the potential effects on the domestic labor market" (Ogawa 2012) and it has been alleged that the Association designed the exam to keep the passing rate low as a protectionist measure (Ohno 2012, p. 550). Inoue (2013) concludes,

"The low ratio of success is the result of conflicting policy interests in a single political arrangement. At the administrative level, the MOFA [Ministry of Foreign Affairs] and the MHLW [Ministry of Health, Labor, and Welfare] take... different positions to the EPA. The MOFA thinks that the EPA contributes to the international exchange of persons and inviting highly skilled persons. However, the MHLW emphasized that the EPA was not regarded as the solution for local staff shortage. Such MHLW's position was parallel to that of the Japanese Nursing Association (JNA), one of the occupational interest group in the healthcare sector. The JNA places a special emphasis on protecting the national labour market..."

This experience highlights the importance of close coordination with destinationcountry labor organizations to prevent political conflict from damaging the program. Programs of this kind are likely to be perceived as a threat and substantial involvement of labor organizations will be required to build trust. Ogawa (2012) predicts that "if Japan continues to enforce the condition for the foreign workers to pass the national exam ... the care facilities may eventually stop accepting them because of the large financial and human cost incurred." 


\subsection{Other key elements}

Additional design elements likely to influence the success of a Global Skill Partnership include:

Bilateral agreement. The movement of skilled workers, particularly health workers, has often occurred in an atmosphere of mistrust and contestation among policymakers. Policymakers at the origin are unlikely to cooperate unless they believe that it is truly designed to foster human capital formation for domestic service. Policymakers at the destination are unlikely to cooperate if they perceive their origin-country counterparts as a potential obstacle. A Bilateral Labor Agreement can make expectations clear without the need for a binding treaty: Sáez (2013) reviews several examples.

Integrity of the 'home' track. Students in the 'home' track of a two-track school would be unlikely to migrate if the program were carefully designed. Graduates of any such program are unlikely to successfully migrate if their skills are not custom-designed for accreditation at the destination, if they receive no specialized language training, and if their work visas are not facilitated in the context of a bilateral agreement.

Social training credit. Parties would need to agree up front to what degree the value generated by migrants in the 'away' track would subsidize the training of non-migrants in the 'home' track.

Language training. Many types of skilled work, certainly including all nursing and personal care work, require excellent skills in the language of the destination country. This must be a major focus of training in the 'away' track. Several of the initiatives discussed above, including the work of GIZ and NNI, show that it is quite possible for trainees to acquire sufficient language skills.

Interministerial coordination. A two-track school arrangement for health workers would likely require cooperation or at least assent from numerous ministries in order to function properly. These might include ministries of health, development aid, labor, immigration, and foreign affairs, and possibly ministries of education and planning. For example, cooperation between the aid and immigration agencies of the Australian government might have helped ensure that more substantial numbers of APTC trainees could access the Australian labor market.

Portability between employers. Employers that participate in financing training in the 'away' track deserve a return on that investment. But there are dangers in tying employees exclusively to a single employer for many years, since an important protection for workers' rights is their ability to leave a job. A successful arrangement should allow for graduates to have the option to 'buy out' their commitment to an employer by working for a second employer and paying making pre-set cash payments to the first.

\section{Conclusion}

More and more skilled workers will move from poor to rich countries in the years to come. There is little question that large-scale movement will happen; the question is on what 
terms it will happen. Skilled people will move, particularly nurses, but there need not be a choice between allowing that movement and stopping fiscal drain at the origin. This note proposes a new form of public-private training partnership to help skilled migration happen on terms more beneficial for origin countries, destination countries, and migrants: Global Skill Partnerships.

The two-track technical school is one form of Global Skill Partnership that maximizes the benefits to everyone involved. Designed correctly, a two-track school can provide destination countries with the skilled workers they will need and good jobs for youths from developing countries, while at the same time helping strengthen human capital stocks and public coffers in migrants' countries of origin. Innovative partnerships like these are better ways to address concerns about skilled migration than alternative policies such as enforcing limits on migration or post-migration compensation payments. Those policies have attempted to reconstruct a world without migration. Global Skill Partnerships, in contrast, are a tool to help policymakers plan for a mobile world.

\section{Endnotes}

${ }^{1}$ Rural US patients depend more on Nurse Practitioners than urban patients for primary care (Everett et al. 2009) and prescriptions (Cipher et al. 2006). This may contribute to the fact that many rural US states with shortages of physicians allow nurse practitioners to make diagnoses or prescribe medicine without physician supervision (such as North Dakota, Wyoming, Idaho, Iowa, and West Virginia), while all the states with the largest cities do not allow this (New York, California, Texas, Illinois). This does not demonstrate that these regulatory differences were caused by physicians' migration patterns, but the existence of greater freedoms for Nurse Practitioners in rural areas does help to accommodate physicians' choices about where to live, helping rural states to get the most out of health professionals who are less likely to leave.

${ }^{2}$ Brazil does this through its National Council for Scientific and Technological Development (CNPq), and Turkey through its Scientific and Technological Research Council (TÜBİTAK).

${ }^{3}$ Converted using exchange rates current at the time of each source's publication.

${ }^{4}$ German Medicine Net SARL (http://www.germanmedicine.net/en/jobsnurses. html) advertised on April 5, 2014 "nursing jobs in hospitals in all parts of Germany" for foreign-trained nurses, paying "ca. 1800-3000 Euros before taxes and social security/month depending on qualification and region, up to 3500 Euros/month with additional qualifications." In 2012-13 the German Federal Employment Agency (http:// www.manila.diplo.de/contentblob/3924096/Daten/3341372/RSF_fil_nurses_to_ Germany.pdf) offered starting salaries in the same range to Filipino nurses through the Philippine Overseas Employment Administration (FM-POEA-04-EF-07-A). In France, the Syndicat National des Professionels Infirmiers (http://www.syndicat-infirmier.com/ IMG/pdf/606_27_grille_IDE.pdf) reports a similar range for starting and early-career wages in France.

${ }^{5}$ The private École Supérieure Privé de Nutrition et du Paramédical in Casablanca (http://www.supsante.ma/formulaireincsription.html) currently charges MAD37,000 per year, plus a one-time MAD3,500 registration fee, for its three-year sciences infirmières course-for a total three-year cost under US $\$ 14,000$. The private Institut Supérieur Privé des Sciences Infirmières de Sousse (ISEPSI) in Sousse, Tunisia (http:// www.etoile-formation.com/homepage_isepsi.html) currently charges TND2,500 or less for each year of its three-year professional nursing course, including registration fee, amounting to a total start-to-finish cost under US\$5,000. 
${ }^{6}$ The University of Witten/Herdecke, a private university in Germany accredited as an Universität equivalent in quality to state-run universities, (http://sg.blog.uni-wh.de/ generationenvertrag/beitragssatze/) charges $€ 12,600$ per semester for its three-year Bachelors in Nursing Practice, for a total cost of $€ 75,600$. The King's College London Florence Nightengale School of Nursing and Midwifery (http://www.kcl.ac.uk/study/ug/ funding/fees/overseas.aspx) currently charges $£ 15,450$ per year in tuition only to non-European foreign students for its three-year Bachelors in nursing, or (inclusive of fees) about US\$80,000 total. These figures do not include any living expenses.

${ }^{7}$ Germany is currently piloting a partnership for geriatric nurses from Vietnam that resembles this arrangement in most aspects except the absence of a 'home' track or Social Training Credit. This is discussed below.

\begin{abstract}
Abbreviations
APTC: Australia-Pacific Technical College; EPA: Economic Partnership Agreement; GIZ: German Society for International Cooperation; ILM: International Labor Mobility; JNA: Japanese Nursing Association; KANI: Kiribati Australia Nursing Initiative; LLC: Limited Liability Company; MHLW: Ministry of Health, Labor, and Welfare; MOFA: Ministry of Foreign Affairs; NAFTA: North American Free Trade Agreement; NCLEX: National Council Licensure Examination; NNI: Nurses Now International; OECD: Organization for Economic Cooperation and Development; TAPiG: Transformationspartnerschaft im Gesundheitswesen ("Transformation Partnership in the Healthcare Sector"); US: United States.
\end{abstract}

\title{
Competing interests
}

The IZA Journal of Labor Policy is committed to the IZA Guiding Principles of Research Integrity. The author declares that he has observed these principles.

\section{Authors' information}

The author is Senior Fellow and Research Manager at the Center for Global Development, a Research Fellow at IZA Institute for the Study of Labor, and an affiliate of the Financial Access Initiative at New York University.

\begin{abstract}
Acknowledgements
This research was supported by the World Bank ILM program at the Center for Mediterranean Integration under the overall supervision of Manjula Luthria, and received additional support from the John D. and Catherine T. MacArthur Foundation, the William and Flora Hewlett Foundation, the Nordic Trust Fund for Human Rights, and Good Ventures. Marla Spivack, Tejaswi Velayudhan, Christian Meyer, and Nabil Hashmi provided excellent research assistance. Helpful ideas also came from Steffen Angenendt, Ottilie Bälz, Stefan Bethe, Nancy Birdsall, Satish Chand, Stephan Hillebrand, Stephen Howes, Natasha Iskander, Benjamin Leo, Akiko Maeda, Francisco Marmolejo, Aaditya Mattoo, Matthias Mayer, David McKenzie, Meiko Merda, Christal Morehouse, Mujobu Moyo, Cağlar Özden, Yann Pouget, Lant Pritchett, Andrea Riester, Kaye Schofield, Madeleine Sumption, Erwin Tiongson, Anna Wittenborg, and Astrid Ziebarth, as well as with participants in seminars at AusAID, the Bosch Foundation, the German Ministry for Economic Cooperation and Development, Rutgers University, and the Université Internationale de Rabat. But the views in this paper and any errors are solely the responsibility of the author; they do not necessarily reflect the opinions of the Center for Global Development or the World Bank, their boards, or their funders. The author thanks the anonymous referee. Responsible editor: Juan F. Jimeno
\end{abstract}

Received: 11 May 2014 Accepted: 5 December 2014

Published online: 29 January 2015

References

Agwu K, Llewelyn M (2009) Compensation for the brain drain from developing countries. The Lancet 373(9676):1665-1666. http://dx.doi.org/10.1016/S0140-6736(09)60927-2

AMA (2010) International medical graduates in American Medicine: contemporary challenges and opportunities. A position paper by the AMA-IMG Section Governing Council, American Medical Association. Chicago, Illinois. http:// nycsprep.com/pdf/international-medical-graduates.pdf

Auerbach DI, Staiger DO, Muench U, Buerhaus PI (2012) The nursing workforce: a comparison of three national surveys. Nursing Econ 30(5):253-260. https://www.nursingeconomics.net/ce/2014/article3005253260.pdf

Avato J (2009) Migration Pressures and Immigration Policies: New Evidence on the Selection of Migrants. SP Discussion Paper 930, World Bank. Washington, DC. http://ideas.repec.org/p/wbk/hdnspu/52449.html

Awases M, Gbary A, Nyoni J, Chatora R (2004) Migration of health professionals in six countries: a synthesis report. World Health Organization AFRO Regional Office, Brazzaville. http://info.worldbank.org/etools/docs/library/206860/ Migration\%20study\%20AFRO.pdf

BLS (2012) Employment Projections 2010-2020. Technical Report, U.S. Bureau of Labor Statistics. http://www.bls.gov/ news.release/ecopro.t06.htm

Buerhaus Pl, Auerbach DI, Staiger DO (2009) The recent surge in nurse employment: Causes and implications. Health Affairs 28(4):w657-w668. http://dx.doi.org/10.1377/hlthaff.28.4.w657

Chang SL (1992) Causes of brain drain and solutions: the Taiwan experience. Stud Comparative Intl Dev 27(1):27-43. http://dx.doi.org/10.1007/BF02687103

Chen PG, Auerbach DI, Muench U, Curry LA, Bradley EH (2013) Policy solutions to address the foreign-educated and foreign-born health care workforce in the United States. Health Affairs 32(11):1906-1913. http://dx.doi.org/10.1377/ hlthaff.2013.0576 
Cipher DJ, Hooker RS, Guerra P (2006) Prescribing trends by nurse practitioners and physician assistants in the United States. J Am Acad Nurse Practitioners 18(6):291-296. http://dx.doi.org/10.1111/j.1745-7599.2006.00133.x

Clemens MA (2009) Skill Flow: A Fundamental Reconsideration of Skilled-Worker Mobility and Development. CGD Working Paper 180, Center for Global Development. Washington, DC. http://www.cgdev.org/publication/skill-flowfundamental-reconsideration-skilled-worker-mobility-and-development-working

Clemens, M A (2011) The financial consequences of high-skill emigration: lessons from African doctors abroad. In: Plaza S, Ratha F (eds). Diaspora for Development in Africa. World Bank, Washington, DC. pp 165-182. http://siteresources. worldbank.org/EXTDECPROSPECTS/Resources/476882-1157133580628/DfD_ch06.pdf

Clemens MA, Graham G, Howes S (2014) Skill Development and Regional Mobility: Lessons from the Australia-Pacific Technical College. CGD Working Paper 370, Center for Global Development. http://www.cgdev.org/publication/skilldevelopment-and-regional-mobility-lessons-australia-pacific-technical-college

Cortés P, Pan J (2012) Relative quality of foreign nurses in the United States. Discussion Paper 31/12, Centre for Research and Analysis of Migration (CReAM), Department of Economics, University College, London. http://www.creammigration.org/publ_uploads/CDP_31_12.pdf

European Commission (2012) Commission Staff Working Document on an Action Plan for the EU Health Workforce. SWD 93 final, European Commission. http://ec.europa.eu/dgs/health_consumer/docs/ swd_ap_eu_healthcare_workforce_en.pdf

Everett CM, Schumacher JR, Wright A, Smith MA (2009) Physician assistants and nurse practitioners as a usual source of care. J Rural Health 25(4):407-414. http://dx.doi.org/10.1111/j.1748-0361.2009.00252.x

George G, Atujuna M, Gow J (2013) Migration of South African health workers: the extent to which financial considerations influence internal flows and external movements. BMC Health Serv Res 13(1):1-8. http://dx.doi.org/10. 1186/1472-6963-13-297

Gish O, Godfrey M (1979) A reappraisal of the 'brain drain'-With special reference to the medical profession. Soc Sci Med Part C: Med Econ 13(1):1-11. http://dx.doi.org/10.1016/0160-7995(79)90020-0

Grignon ML, Yaw O-A, Sweetman A (2012) The International Migration of Health Professionals. IZA Discussion Paper 6517, Institute for the Study of Labor (IZA). http://www.iza.org/en/webcontent/publications/papers/viewAbstract?dp_id= 6517

HWA (2012) Health Workforce 2025. Health Workforce Australia, Canberra. https://www.hwa.gov.au/sites/uploads/ HW2025Volume2_FINAL-20120424.pdf

Inoue J (2013) Healthcare: the case of Japan. Migration Lett 10(2):191-209. http://www.tplondon.com/journal/index.php/ $\mathrm{ml} /$ article/view/6

Joint Learning Initiative (2004) Human resources for health: overcoming the crisis. Harvard University Global Equity Initiative, Cambridge, MA. http://www.who.int/hrh/documents/JLi_hrh_report.pdf

Jokinen H (2013) JHL gives grants to Philippine practical nurses. July 10. JHL: The Trade Union for the Public and Welfare Sectors, Helsinki. http://www.jhl.fi/portal/en/jhl_info/news/?bid=3019

Kirigia JM, Gbary AR, Muthuri LK, Nyoni J, Seddoh A (2006) The cost of health professionals' brain drain in Kenya. BMC Health Serv Res 6(1):89. http://dx.doi.org/10.1186/1472-6963-6-89

Lautier M (2005) Les exportations de services de santé des pays en développement: Le cas tunisien. Notes et Documents, Numéro 25, Agence Française de Développement, Paris. http://www.afd.fr/webdav/site/afd/shared/PUBLICATIONS/ RECHERCHE/Archives/Notes-et-documents/25-notes-documents.pdf

Lebsir M (2009) La fuite des blouses blanches. Syndicat National des Médecins du Secteur Libéral, Casablanca, Morocco. Accessed April 52014

Little L (2007) Nurse migration: a Canadian case study. Health Serv R 42(3):1336-1353. http://dx.doi.org/10.1111\%2Fj. 1475-6773.2007.00709.x

Mattoo A, Subramanian A (2013) Criss-crossing migration. Policy Research Working Paper 6539. World Bank, Washington, DC. http://documents.worldbank.org/curated/en/2013/07/18029114/criss-crossing-migration

Mattoo A, Rathindran R (2006) How health insurance inhibits trade in health care. Health Affairs 25(2):358-368. http://dx. doi.org/10.1377/hlthaff.25.2.358

McCabe K, Lin SY, Tanaka H, Plewa P (2009) Pay to go: countries offer cash to immigrants willing to pack their bags. Migration Information Source feature story. Migration Policy Institute, Washington, DC. http://www. migrationinformation.org/Feature/display.cfm?!D $=749$

Mills EJ, Kanters S, Hagopian A, Bansback N, Nachega J, Alberton M, Au-Yeung CG, Mtambo A, Bourgeault IL, Luboga S et al. (2011) The financial cost of doctors emigrating from sub-Saharan Africa: human capital analysis. BMJ: British Med J 343. http://dx.doi.org/10.1136/bmj.d7031

Mills E J, Schabas WA, Volmink J, Walker RB, Ford N, Katabira E, Anema A, Joffres M, Cahn P, Montaner J (2008) Should active recruitment of health workers from sub-Saharan Africa be viewed as a crime? Lancet 371(9613):685-688. http://www.sciencedirect.com/science/article/pii/S0140673608603086

Muula AS, Panulo B, Maseko FC (2006) The financial losses from the migration of nurses from Malawi. BMC Nursing 5(1):9. http://dx.doi.org/10.1186/1472-6955-5-9

Norcini JJ, Boulet JR, Dauphinee WD, Opalek A, Krantz ID, Anderson ST (2010) Evaluating the quality of care provided by graduates of international medical schools. Health Affairs 29(8):1461-1468. http://dx.doi.org/10.1377/hlthaff.2009. 0222

OECD (2007) International Migration Outlook: SOPEMI 2007 Edition. OECD Publishing, Paris. http://dx.doi.org/10.1787/ migr_outlook-2007-en

Ogawa R (2012) Globalization of care and the context of reception of Southeast Asian care workers in Japan. Southeast Asian Stud 49(4):570-593. http://hdl.handle.net/2433/158297

Ohno S (2012) Southeast Asian nurses and caregiving workers transcending the national boundaries: an overview of Indonesian and Filipino workers in Japan and abroad. Southeast Asian Stud 49(4):541-569. http://hdl.handle.net/ 2433/158298

Oveido M (2009) Bilingües y capacitadas, igual a un sueldo en dólares. Hora Cero (Nuevo León, Mexico), November 23, 12-14. http://nni.com.mx/noticias/07_010111_hc_local_bilinguesycapacitadasigualaunsueldoendolares.pdf 
Pack H, Pack JR (2009) Foreign aid and the question of fungibility. Rev Econ Stat 75(2):258-65. http://www.jstor.org/ stable/2109431

Reid, T (2011) Suspended: Charles halts, Canadian nurses training programme. May 15. Jamaica Gleaner, Kingston, Jamaica. http://jamaica-gleaner.com/gleaner/20110515/lead/lead2.html

Reid T (2012) Nurses seek new remedy. March 4, Jamaica Gleaner. http://jamaica-gleaner.com/gleaner/20120304/news/ news3.html

Sáez S (2013) Let workers move: using bilateral labor agreements to increase trade in services. World Bank, Washington, DC. http://dx.doi.org/10.1596/978-0-8213-9915-6

Saxenian A (2002) The Silicon Valley connection: transnational networks and regional development in Taiwan, China and India. Sci Technol Soc 7(1):117-149. http://dx.doi.org/10.1177/097172180200700106

Spetz J, Given R (2003) The future of the nurse shortage: Will wage increases close the gap? Health Affairs 22(6):199-206. http://dx.doi.org/10.1377/hlthaff.22.6.199

Squires, Allison, Hiram Beltrán-Sánchez (2013) Strengtheni ng Health Systems in North and Central America: What role for migration? Report of the Regional Migration Study Group. Wilson Center and Migration Policy Institute, Washington, DC. http://www.migrationpolicy.org/pubs/RMSG-HealthCare.pdf

Verboom P, Tan-Torres E, Evans DB (2006) The costs of eliminating critical shortages in human resources for health. Background paper for the World Health Report 2006, World Health Organization, Geneva. http://www.who.int/ choice/publications/d_human_resources.pdf

WHO (2006) World Health Report 2006: Working together for health. World Health Organization, Geneva. http://www. who.int/whr/2006/en/

WHO (2011) The WHO Global Code of Practice on the International Recruitment of Health Personnel. World Health Organization, Geneva. http://www.who.int/hrh/migration/code/code_en.pdf

WHO (2014) Global Atlas of the Health Workforce. Technical Report, Geneva. http://apps.who.int/globalatlas/default.asp Wildau B (2011) Filipino Nurses Receive their Finnish Nursing Degrees. June 2, ScandAsia.com, Bangkok, Thailand. http:// scandasia.com/8938-filipino-nurses-receive-their-finnish-nursing-degrees/

\section{Submit your manuscript to a SpringerOpen ${ }^{\circ}$ journal and benefit from:}

- Convenient online submission

- Rigorous peer review

- Immediate publication on acceptance

- Open access: articles freely available online

- High visibility within the field

Retaining the copyright to your article

Submit your next manuscript at $\gg$ springeropen.com 